\title{
Efficiency of the convergent ladybird beetle Hippodamia convergens against the legume aphid Aphis craccivora in laboratory and semi-felid conditions.
}

\author{
Hadeer, S. A. Rashed; Naglaa, F. Abd-Elhameid; Adel, A. Hafez and Fawzy, F. Shalaby \\ Plant Protection Department, Faculty of Agriculture, Moshtohor, Benha University, Egypt. \\ Corresponding author: hadeerrashed123@gmail.com
}

\begin{abstract}
Laboratory and semi-field studies were conducted to investigate some biological parameters, feeding capacity and releasing efficiency of Hippodamia convergens on legume aphid, Aphis craccivora. At $25 \pm 2^{\circ} \mathrm{C}$ and $65 \pm 5$ R.H., durations of the eggs' incubation period, the four larval instars and pupae were 4.48, 2.11, 2.23, 2.23, 2.68 and 4.39 days, respectively. The average feeding of the $4^{\text {th }}$ instar larvae fed on 84.47 aphids of $4^{\text {th }}$ nymphal instar, being the highest voracious feeder compared to the first three larval instars which consumed the means of 14.4, 21.3 and 32.87 individuals, respectively. When fed on A. craccivora nymphs, female survived longer (50.83 days) than male (34.73days), a single $H$. convergens female deposited average total of $455.13 \mathrm{eggs}$.

The semi-field studies evaluated the controlling capacity against infestation by A. craccivora on faba bean seedlings by $H$. convergens released under greenhouse conditions, as; only adults, only $3^{\text {rd }}$ instar larvae and both stages. Either of the three treatments for releasing Hippodamia caused reductions of aphid densities than control. In experiment one; 3, 9 and 15 adults/plot were released only one time. Ten days after release, the treatment receiving 15 adults/plot showed the highest reduction rate in aphids $(100.00 \%)$ compared to that received 3adults $(86.78 \%)$ or 9 adults $(95.41 \%)$ /plot. In the second treatment; 3, 9 and 15 larvae/plot were released one week after infestation, reduction rate of $96.93 \%$ occurred 10 days after releasing of 15 larvae/plot. In the third experiment; both stages altogether were released at 3 ratios, i.e., 1adult:2 larvae, 3 adults:6 larvae and 5adults: 10larvae/plot. The highest reduction rate $(99.14 \%)$ of A. craccivora occurred by the third treatment (5A:10L/plot) after 13 days from the releasing date. Treatment receiving only adults showed the highest reduction rate of $A$. craccivora densities compared to the two other treatments. Accordingly, releasing $H$. convergens adults only was better than the other two treatments for control of A. craccivora infestations.
\end{abstract}

Key words: Hippodamia convergens-Aphis craccivora-Biology - Release.

\section{Introduction}

Intensive use of pesticides for insect pests control has led to several problems such as, development of insects' resistance to insecticides, disturbing the natural balance between beneficial natural enemies and target pests, and phytotoxicity and secondary pests' outbreaks. That directed the researchers towards development of integrated management strategies in which the biological control methods were represented as a main component (Hale and Elliott, 2003 and Schirmer et al., 2006). In this respect, using biological control especially predators, in insect pest management programs received increasing attention (Atlihan and Kaydan, 2010). Insect predators are of the major groups of biological control agents used for aphids' control. The majority of those belonging to Coccinellidae comprise one of the most important active predatory species, that feed during the larval and adult stages on different small sap-sucking pests as well as some other small insect species.

Coccinellids have been successfully released and established in glasshouse crops such as tomato, sweet peppers and cucumbers. Those feed on diverse pest species including aphids, thrips, whiteflies, mites and lepidopteran eggs (Omkar, 2004).In addition, determination of oviposition and egg laying behavior strategies of the natural enemy, greatly, helps in better understanding its biological and ecological characteristics, which determine its offspring's efficiency and population growth rate (Abdel-Salam and Abdel-Baky, 2001; Lee and Kang, 2004; Shrestha and Parajulee, 2013 and Yu et al., 2013). Also, the successful natural enemies that which shows high reproduction rate and searching ability for the target pest, and ecologically synchronized with its host or prey (Buchanan, 1996).

The convergent ladybird beetle Hippodamia convergens Guérin-Méneville, is an important predator of many aphid species (Lyon, 1998). These predatory beetles contribute in regulation of the prey populations, (Lyon, 2001). After hatching of $H$. convergens eggs, the young larvae start searching for soft bodied small insects for feeding. Adults and older larvae are voracious feeders. It is one of the few natural enemies that are currently wild-collected from mass aggregations for pest control industry (Aristizábal and Steven, 2015). The consumption rate of the larvae of $H$. convergens has shown a positive correlation between the developmental stages of carnivorous larvae and the amount of Melanaphis sacchari individuals consumed. By evaluating the consumption rate of $H$. convergens by larval instars, results showed that the fourth larval 
instar consumed a greater number of preys than did the adult stage (Ramírez, et al., 2019).

The natural sequence role $H$. convergens must be continuously encouraged and developed by maintaining the suitable safe conditions to play and to naturally increase this role. $H$. convergens can massed reared in the laboratory and released for controlling the aphids' species attacking the wheat plants or the other related plants that are subjected to the aphids' infestation (Bahy El-Din and ElKhawas, 2020).

\section{The presented study aimed to:}

a. Studying the biology of $H$. convergens on $A$. craccivora Koch under laboratory conditions.

b. Evaluating the effect of releasing different stages of $H$. convergens at different rates for aphids control under semi-field conditions.

c. Detecting the most effective predator rate and stage to be released for aphid control.

Materials and Methods

1. Insects stock cultures:

\subsection{The black legume aphid $A$. craccivora:}

A. craccivora infestations on faba bean seedlings were, principally, obtained from Syngenta Company for Agrochemicals and Seeds, Kaha Qalubiya Governorate. Infested plant parts were transferred to the biological control laboratory for mass-rearing of aphid and beneficial bio-agents. Stock culture of this aphid species was maintained in the laboratory on faba bean seedlings grown in wet sawdust placed in plastic containers $(30 \mathrm{~cm}$. length, $15 \mathrm{~cm}$. width and $4 \mathrm{~cm}$. height). These containers were placed in muslin screen cages $(30 \mathrm{~cm}$ diameter and $60 \mathrm{~cm}$ height) and kept in the laboratory under the natural available conditions $\left(25 \pm 2^{\circ} \mathrm{C}\right.$ and $65 \pm 5 \%$ R.H.). Through parthenogenesis, multiplication quickly took place and dense culture of A. craccivora became available for the following needed experiments.

\subsection{The coccinellid Hippodamia convergens:}

$H$. convergens individuals were collected from the open fields of Qalubiya Governorate and introduced to the laboratory of biological control of the college, under laboratory conditions for carrying out the main experiments. Mass rearing of the predator was followed using the following method: five pairs (males and females) of the coccinellid predator were placed in woody boxes $(15 \mathrm{~cm}$ length, $10 \mathrm{~cm}$ width and $15 \mathrm{~cm}$ height), covered from the sides with muslin cloth pieces and provided with strips of black paper for egg-laying. The predator was provided with planted faba bean seedlings infested with adequate numbers of $A$. craccivora individuals to serve as food. Adult females deposited their eggs either on the underside of faba-bean leaves or on the black paper strips. The deposited eggs were, daily, collected with the oviposition substrate, counted and placed in Petri-dishes. After hatching, the neonate larvae were provided, daily, with adequate numbers of aphids for feeding, until pupation. Resultant pupae were subsequently kept in other jars until adults' emergence. The resultant adults were taken to start the designed studies.

2. Developmental periods of different $H$. convergens stages:

2.1. Incubation period of eggs and hatchability percentages:

A group of freshly deposited 50 eggs each, resulted from adult females that were reared on $A$. craccivora, were transferred to clean Petri-dishes until hatching. The experiment was replicated five times. Hatching date was recorded for estimating the incubation period of eggs and calculating hatchability and mortality percentages.

\subsection{Durations of larval and pupal stages and larval feeding capacity}

After hatching, the neonate larvae were placed singly in plastic cups $(5 \mathrm{~cm}$ diameter) in which a filter paper was placed on the bottom of each cup. Each larva was daily provided with counted enough number of $A$. craccivora individuals of the $4^{\text {th }}$ nymphal instar placed on piece of faba bean seedling for aphid survival. The number of daily consumed individuals by larva was counted until the predaceous larva reached the pupal stage. Durations of each of the four larval instars were estimated depending upon the presence of the larval exuviae. The resultant pupae were placed singly in a plastic container and left until emergences of adults. At the time of emergence the pupal durations was estimated. Mortalities among larvae and pupae were recorded. Also, adults' emergence and mortality percentages were also, calculated. All estimations were made on 15 replicates.

\subsection{Longevity and fecundity of $H$. convergens adults}

Fifteen freshly emerged couples of $H$. convergens, representing 15 replicates were used in this experiment. Every couple of the predator $(q$ and 3) was confined in a glass tube $(3 \mathrm{~cm}$ diameter and 8 $\mathrm{cm}$ height) and supplied with faba bean seedlings infested with suitable number of A. Craccivora individuals (nymphs and adults). Strips of black paper were also placed in each tube as oviposition substrate. Longevities of adults, fecundity/female, ovipositional periods, hatchability percentage and the total deposited eggs were also estimated.

\section{Semi-field experiments under greenhouse conditions:}

Semi-field experiments were carried out in the small built greenhouse ( $3 \mathrm{~m}$ diameter, $7 \mathrm{~m}$ length and $4 \mathrm{~m}$ height) of the Plant Protection Department, Faculty of Agriculture at Moshtohor during the faba bean season 2018/2019. The experiments started on January, 2019. Each of the adults, the $3^{\text {rd }}$ instar larvae and combinations of the two stages at three ratios were released for controlling the faba bean aphids infesting faba bean seedlings. The experiments were carried out using the following steps:
a. Planting in the screen-house: 
For one day, faba bean seeds were soaked and planted in the next day inside plastic pots (3seeds/pot). Twenty seven pots (no. 30) were placed in the screen house, these screen house divided into 3 plots each plot contained 3 replicates, each replicate contained 3 pots, on each pot three seeds of faba bean were presented. A week after appearance of faba bean seedlings and reaching a suitable length for infestation $(7-10 \mathrm{~cm})$, they were infested with $A$. craccivora individuals which maintained from biological control laboratory of the college. Each pot was infested with thirty $A$. craccivora adults. When the infestation reached a high level, the different releases of the predator were carried out.

\section{b. Releasing of the predator:}

Adults (A), the third instar larvae $\left(\mathrm{L}_{3}\right)$ and mix of adults and larvae $\left(\mathrm{A}: \mathrm{L}_{3}\right)$ were released at three different rates. At first, the numbers of $A$. craccivora on seedlings were counted before releasing the predator stages. For each treatment 9,27 and 45 predator were released as a total number, for the first, second and third treatment, respectively. As for the first experiment with adult releasing; 3adults/plot were released for the first treatment, (1 adult / pot), on the second 9 adults/plot ( 3 adults/ pot) and the third was 15 adults /plot (5 adults/ pot) each pot contained 3 seedlings. The same technique was followed on larvae releasing, while for the third experiment with mix of larvae and adults releasing; 1adult:2larvae/plot were released for the first treatment, on the second 3 adults: 6 larvae/plot and the third was 5 adults: 10 larvae/plot each plot contained 3 pots.

The numbers of aphid individuals were counted before releasing, then after $3,5,7$ and 10 days for larvae and it extended to 15 and 17 days in the other two treatments.

\section{Statistical analysis}

Statistical analysis was carried out using twoway ANOVA using SPSS, ver.22 (IPM Crop. Released 2013). Data were treated as a complete randomization design according to Steel et al., (1997).

\section{Results and Discussion}

1. Biology of Hippodamia convergens reared on A. craccivora:

\subsection{Incubation period of eggs:}

As shown in Table (1), mean of incubation period of Hippodamia convergens eggs obtained after rearing on A. craccivora individuals (adults and nymphs)at $25 \pm 2{ }^{\circ} \mathrm{C}$ and $65 \pm 5 \%$ R.H., was 4.48 days. As shown in Table (2), the hatchability percentage from the deposited eggs reached $94.00 \%$, indicating $(6.00 \%)$ mortality percentage. In similar studies, ElHeneidy et al., (2008) recorded that, the mean incubation period of $H$. convergens eggs was 4.32 days after rearing on $A$. craccivora $4^{\text {th }}$ nymphal instar at $23 \pm 2^{\circ} \mathrm{C}$ and $65 \pm 5 \%$ R.H., this period is almost the same as the 4.48 days in spite of the difference in rearing temperature.

\subsection{Larval and pupal durations:}

In this experiment, the freshly hatched larvae of $H$. convergens were fed on the $4^{\text {th }}$ nymphal instar of $A$. craccivora throughout the whole larval period. Data presented in Table (1), indicated that the first three larval instar durations were, nonsignificantly, different being $\left(2.11,2.23\right.$ and 2.23 days, for the $1^{\text {st }}$, $2^{\text {nd }}$ and $3^{\text {rd }}$ larval instars, respectively), only the $4^{\text {th }}$ larval instar showed significant elongation in duration compared to either of the three larval instars, being ( 2.68 days). Also, means of the total larval duration lasted 9.25 days. Throughout the whole total larval period, there were no mortalities after rearing on $A$. craccivora $4^{\text {th }}$ nymphal instar (Table, 2). The consumption rate/larva of $H$. convergens increased as the predator larvae grew older to the subsequent instar. When fed on the $4^{\text {th }}$ nymphal instar of $A$. craccivora, a single larva consumed 14.40, 21.13, 32.87 and 84.47 nymphs during the $1^{\text {st }}, 2^{\text {nd }}, 3^{\text {rd }}$ and $4^{\text {th }}$ larval instars of the predator, respectively. Throughout the total larval stage a single $H$. convergens larva consumed a mean 152.87 A. craccivora $4^{\text {th }}$ instar nymphs, (Table, 2). The mean period of $H$. convergens pupa resulted from larvae reared on the $4^{\text {th }}$ nymphal instar of $A$. craccivora was 4.39 days (Table,1). The percentages of adults' emergence from pupae obtained after rearing on aphid nymphs during the larval stage (Table, 2) were $93.33 \%$ emergence of adults fed on A. craccivora. These results were similar to those of El-Heneidy et al., (2008), which indicated that the durations of the $1^{\text {st }}, 2^{\text {nd }}, 3^{\text {rd }}$ and $4^{\text {th }}$ larval instars of the predator when fed on the $4^{\text {th }}$ nymphal instars of A. craccivora. $23 \pm 2^{\circ} \mathrm{C}$ and $65 \pm 5$ R.H., were 1.86 , $1.91,1.97$ and 3.10 days, respectively. Under the same conditions, the same authors found that the pupal stage lasted 4.36 days. Also, Loharet al., (2012) studied the biology and feeding preference of $H$. convergence on mustard aphid, Lipaphis erysimi, and found that the incubation period of eggs was 3.6 days and larval durations of the 4instars were 1.8, 2.4, 2.6 and 2.1 days, respectively. The same author recorded that the consumption rate for the $1^{\text {st }}, 2^{\text {nd }}, 3^{\text {rd }}$ and $4^{\text {th }}$ larval instars was; $18.81,30.67,52.65$ and 70.04 aphid individuals/ day, respectively, and consumed 172.17 individuals as a total larval consumption. The $3^{\text {rd }}$ and $4^{\text {th }}$ instars are voracious feeders as compared to the $1^{\text {st }}$ and $2^{\text {nd }}$ instars. These results are close to the results of the present study results with the differences of aphid species. 
Table 1. Developmental periods of different stages of Hippodamia convergens reared on legume aphid, Aphis craccivora under laboratory conditions.

\begin{tabular}{lcc}
\hline Life stage and instars & & Mean (days) \\
\hline Egg incubation period & $\mathbf{1}^{\text {st }}$ & $4.48 \pm 0.23$ \\
& $2^{\text {nd }}$ & $2.11 \pm 0.03^{\mathrm{a}}$ \\
Larval stage & $\mathbf{3}^{\text {rd }}$ & $2.23 \pm 0.11^{\mathrm{a}}$ \\
& $\mathbf{4}^{\text {th }}$ & $2.23 \pm 0.07^{\mathrm{a}}$ \\
Pupal stage & Total larval period & $2.68 \pm 0.17^{\mathrm{b}}$ \\
Total developmental period & & $9.25 \pm 0.12$ \\
Male longevity & & $4.39 \pm 0.32$ \\
Female longevity & & 18.12 \\
& & $34.73 \pm 0.36$ \\
Ovipositional period & Pre- oviposition & $50.78 \pm 0.55$ \\
& Oviposition & $6.78 \pm 0.20$ \\
\hline
\end{tabular}

a, b \& c: There is no significant difference $(\mathrm{P}>0.05)$ between any two means, within the same column have the same superscript letter.

Table 2. Some biological parameters of Hippodamia convergens reared on legume aphid, Aphis craccivora under laboratory conditions.

\begin{tabular}{|c|c|c|}
\hline $\operatorname{Egg}(\%)$ & $\begin{array}{l}\text { Hatchability (\%) } \\
\text { Mortality (\%) }\end{array}$ & $\begin{array}{c}94.00 \pm 1.79 \\
6.00 \pm 1.79\end{array}$ \\
\hline \multirow{5}{*}{ Larval consumption (individual/day) } & $1^{\text {st }}$ & $14.40 \pm 0.70^{\mathrm{d}}$ \\
\hline & $2^{\text {nd }}$ & $21.13 \pm 0.89^{c}$ \\
\hline & $3^{\text {rd }}$ & $32.87 \pm 2.09^{\mathrm{b}}$ \\
\hline & $4^{\text {th }}$ & $84.47 \pm 2.17^{\mathrm{a}}$ \\
\hline & Total consumption & $152.87 \pm 3.29$ \\
\hline \multirow[t]{2}{*}{ Total Larval mortality (\%) } & & 0.00 \\
\hline & Adult emergence rate $(\%)$ & 93.33 \\
\hline \multirow[t]{2}{*}{ Pupae (\%) } & Mortality (\%) & 6.67 \\
\hline & Sex ratio $(0:$ : $)$ & $1: 1.33$ \\
\hline \multicolumn{2}{|c|}{ Total no. of eggs laid by female (eggs/female) } & $455.13 \pm 13.64$ \\
\hline
\end{tabular}

$\mathrm{a}, \mathrm{b} \& \mathrm{c}$ : There is no significance $(\mathrm{P}>0.05)$ between any two means that have the same superscript letter within the same column.

\subsection{Ovipositional periods and longevity of $\boldsymbol{H}$. convergens adults:}

After rearing $H$. convergens adults $(q$ and $\widehat{\delta})$ on $A$. craccivora individuals, the females started egglaying after a pre-oviposition period of 6.78 days. As for the oviposition period, it lasted, 36.27 days, while, the post-oviposition period was 7.73days. Also, as shown in table (1), adult females of $H$. convergens lived longer (50.78 days) than males (34.73 days) fed on $A$. craccivora individuals (Table, 1). Data presented in table (2), indicated that the total number of eggs laid by a single $H$. convergens female was 455.13 eggs / female.

These results are largely consistent with the results of El-Heniedy $\boldsymbol{e t}$ al. (2008), which indicated that Hippodamia convergens female's longevity was 48.80 days being longer than males (39.45 days) when reared on the $4^{\text {th }}$ nymphal instar of Aphis craccivora. Loharet al., (2012) indicated that the average oviposition and post-oviposition periods of Hippodamia convergens reared on mustard aphid, $L$. erysimi were (32.0 and 2.9), respectively, and mean fecundity/female was $(312.3 \pm 9.51 \mathrm{eggs})$.
2. Evaluation of releasing $\boldsymbol{H}$. convergens stages for $A$. craccivora control under semi-field experiments (greenhouse):

As previously mentioned, first infestations by aphids were made by laboratory reared releasing adults of $A$. craccivora at a rate of 30 aphid adults/faba bean seedling. One week later, aphid population increased gradually, and then the predatory stages were released.

\subsection{Efficiency of $\boldsymbol{H}$. convergens adults released} for $A$. craccivora control:

As for releasing the adult stage, 7 days old $H$. convergens adults were released at 3 rates, being, 3 , 9 and 15 adults / plot. The numbers of aphids/ plot were counted before release; the counted numbers of aphids were 1276.33, 1367.00 and 1642.00 individuals before releasing at the three rates of $H$. convergens (adults/plot), respectively. From data presented in Table (3) and Fig.(1), counted aphid population densities decreased as the number of adults released were increased, also the infestation disappeared earlier on the plants which received 
higher numbers of adults (15adults/plot) followed by 9 and 3 adults/plot.

Three days after release, the means of aphid counts became 917.67, 833.33 and 924.67 aphid individual/plot after releasing 3, 9 and 15 adults/plot, respectively, indicating reduction percentages of $28.09 \%, 35.04 \%$ and $43.69 \%$, respectively than numbers before release. While, 5 days after release, aphid population numbers decreased again to reach 567.67, 514.67 and 381.00 aphid individuals/plot, indicating reduction percentages of $55.52 \%, 62.34$ $\%$ and $76.79 \%$ for releasing 3, 9 and 15 adults/plot, respectively (Table, 3 and Fig. 1).

A. craccivora counts re-decreased after 7 days of release until reached 343, 207.33 and 132 individuals for the 3 rates of adults' releasing, respectively, showing higher reduction percentage of $73.13,84.84$ and $91.96 \%$, respectively, than control. Highest reduction rates in aphid counts, compared to population before release were detected 10 days after release, being, $86.78 \%, 95.41 \%$ and $100 \%$, respectively (Table,3 and Fig.1). These reduction rates indicated that releasing 15 adults / plot were enough for consumption of all the counted 1642 aphid individuals and their progeny within 10 days after release.

As shown in Table, (3) and Fig. (1), releasing $H$. convergens adults at lower rates (3 and 9 adults/plot), lower efficiency against $A$. craccivora occurred. The aphid numbers after 13 days of release decreased to 80.67 individuals for 3 adults released, thirteen days after release, the aphid numbers became, 80.67 individuals indicating $93.68 \%$ reduction in aphid population opposed to 12.33 aphid individuals/ plot and $99.1 \%$ reduction for the 9 released adults treatment. The correspondent values of aphid counts and reduction percentages recorded, 15 days of release reached 7.67 individuals and 99.4\% (3 adults), while infestation, completely, disappeared by releasing 9 adults/ plot (100\% consumption) (Table, 3 \&Fig. 1).

From data presented in Table,(3), statistical analysis revealed that there were significant differences between mean counts of $A$. craccivora in control and different treatments, at different rates after releasing $H$. convergens adults. Also, the infestation disappeared after 10 days from releasing 15 adults/plot confirming $100 \%$ consumption of $A$. craccivora and after 15 days from releasing 9 adults/ plot which caused also $100 \%$ reduction opposed to 99.4 reduction by releasing at $3 \mathrm{H}$. convergens adults/plot.

\subsection{Releasing $\boldsymbol{H}$. convergens $3^{\text {rd }}$ instar larvae.}

A. craccivora populations increased until it reached 1104 aphid individuals in the control treatment, opposed to, 1006.67, 1014.33 and 998.33 aphid individuals/plot before releasing $H$. convergens $3^{\text {rd }}$ instar larvae at three rates; 3, 9 and 15 predator's larvae/plot, respectively (Table, 4 and Fig. 2). Three days after releasing of $H$. convergens larvae at 3, 9 and 15 larvae/plot, clearly, the A. craccivora counts decreased in the three treatments to $743.33,656.67$ and 600.33 aphid individuals/plot, representing reduction percentages of $26.15,35.23$ and $39.87 \%$, respectively. Two days later (5 days after release), the percentages of A. craccivora population reduction increased to to $49.00,66.27$ and $76.30 \%$, respectively, while after 7 days of release,

Table 3. Effect of releasing $H$. convergens adults at three different rates on aphid population and reduction percentages compared to control (without releasing) under semi-field conditions.

\begin{tabular}{|c|c|c|c|c|c|c|c|}
\hline \multirow{2}{*}{$\begin{array}{ll}\text { No. } & \text { of } \\
\text { Adults/plot }\end{array}$} & \multirow{2}{*}{$\begin{array}{l}\text { Aphid counts } \\
\text { before release }\end{array}$} & \multicolumn{6}{|c|}{ Period after release } \\
\hline & & 3 days & 5 days & 7 days & 10 days & 13 days & 15 days \\
\hline Control & $1104.00 \pm 21.55^{\mathrm{dG}}$ & $1292.67 \pm 46.80^{\mathrm{aF}}$ & $1571.67 \pm 17.32^{\mathrm{aE}}$ & $1764.00 \pm 32.15^{\mathrm{aD}}$ & $1989.67 \pm 30.03^{\mathrm{aC}}$ & $2182.00 \pm 37.85 a B$ & $2353.67 \pm 68.22^{\mathrm{aA}}$ \\
\hline 3A/plot & $1276.33 \pm 154.10^{\mathrm{cA}}$ & $917.67 \pm 47.51^{\mathrm{bB}}$ & $567.67 \pm 37.49^{\mathrm{bC}}$ & $343.00 \pm 29.74^{\mathrm{bD}}$ & $168.67 \pm 13.09^{\mathrm{bE}}$ & $80.67 \pm 6.84^{\mathrm{bE}}$ & $7.67 \pm 4.10^{\mathrm{bF}}$ \\
\hline $\begin{array}{l}\text { Aphid } \\
\text { population\% }\end{array}$ & 100.00 & 71.91 & 44.47 & 26.87 & 13.22 & 6.32 & 0.60 \\
\hline $\begin{array}{l}\text { Aphid } \\
\text { reduction \% }\end{array}$ & 0.00 & 28.09 & 55.52 & 73.13 & 86.78 & 93.68 & 99.40 \\
\hline 9A/plot & $1367.00 \pm 135.43^{\mathrm{bA}}$ & $833.33 \pm 73.56^{\mathrm{cB}}$ & $514.67 \pm 16.18^{\mathrm{bC}}$ & $207.33 \pm 31.97^{\mathrm{cD}}$ & $62.67 \pm 26.39^{\mathrm{cE}}$ & $12.33 \pm 6.17^{\mathrm{bcE}}$ & 0.0 \\
\hline $\begin{array}{l}\text { Aphid } \\
\text { population\% }\end{array}$ & 100.00 & 64.96 & 37.64 & 15.16 & 4.58 & 0.90 & 0.0 \\
\hline $\begin{array}{l}\text { Aphid } \\
\text { reduction \% }\end{array}$ & 0.00 & 35.04 & 62.34 & 84.84 & 95.41 & 99.10 & 100 \\
\hline $15 \mathrm{~A} /$ plot & $1642.00 \pm 184.35^{\mathrm{aA}}$ & $924.67 \pm 105.78^{\mathrm{bB}}$ & $381.00 \pm 70.66^{\mathrm{cC}}$ & $132.00 \pm 38.85^{\mathrm{dD}}$ & 00.00 & 0.0 & 0.0 \\
\hline $\begin{array}{l}\text { Aphid } \\
\text { population\% }\end{array}$ & 100.00 & 56.31 & 23.20 & 8.03 & 00.0 & 0.0 & 0.0 \\
\hline $\begin{array}{l}\text { Aphid } \\
\text { reduction \% }\end{array}$ & 0.00 & 43.69 & 76.79 & 91.96 & 100.00 & 100 & 100 \\
\hline
\end{tabular}

$\mathrm{a}, \mathrm{b} \& \mathrm{c}$ : There is non significant difference $(\mathrm{P}>0.05)$ between any two means, within the same column having the same superscript letter. 
A, B \& C: There is non significant difference $(\mathrm{P}>0.05)$ between any two means, within the same row having the same superscript letter.

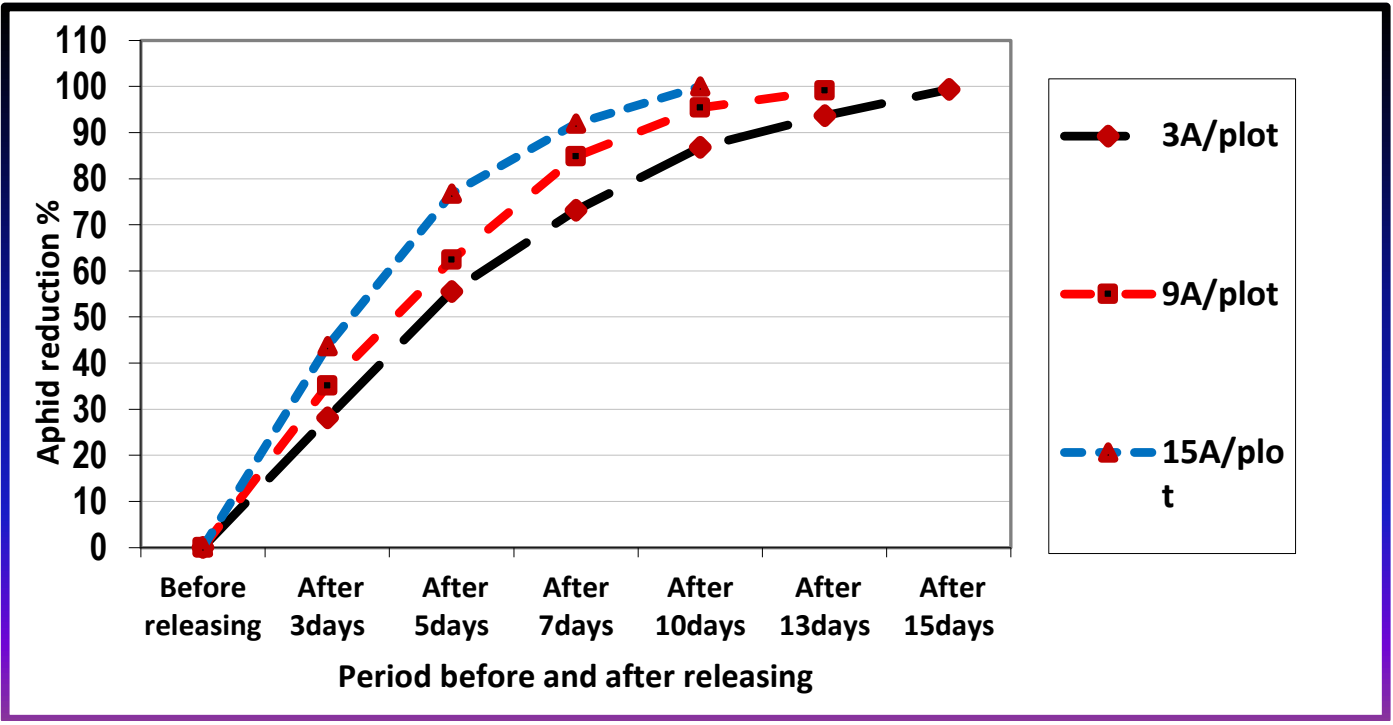

Fig. (1): Reduction percentages in A. craccivora populations after releasing three rates of Hippodamia convergens adults.

the decrease in aphid counts decreased to 405, 155.33 and 93.33 individuals showing re-increasing in reduction percentages than control i.e. 59.74, 84.69 and $90.66 \%$ for releasing at the same 3 rates, respectively. Ten days after release, the released larvae were transferred to pupae and at the same time the aphid counts were decreased to $230.33,56.33$ and 30.67 individuals/plot, respectively, indicating reduction percentage of $77.11,91.5$ and $96.93 \%$ for the three releasing rates 3,9 and 15 larvae/plot, respectively (Table, 4$)$.

\subsection{Releasing both of $\boldsymbol{H}$. convergens adults and larvae altogether:}

In this experiment, a combination of adults and $3^{\text {rd }}$ instar larvae of $H$. convergens was released at three different rates; 1 adult: 2 larvae, 3 adults: 6 larvae and 5 adults: 10 larvae/plot. Before release, the aphid counts in cages specified for releasing at the three rates were $1276.33,1367.00$ and 1642.00 aphid individuals/ plot. Three days after release, these numbers were found to be decreased to 861.00, 748.67 and 647.00 aphid individuals/ plot, indicating reduction percentages; $20.71 \%, 34.73 \%$ and $42.18 \%$, respectively, by the action of releasing both stages altogether (Table, 5 and Fig. 3). Seven days after release at the three ratios, the reduction percentages in aphid counts increased to 59.45, 67.83 and76.91 $\%$, respectively.

Ten days after release, the reduction percentages continued to increase until reaching $70.20,80.42$ and $88 \%$, respectively, for the 3 rates of adults: larvae/plot, respectively. Thirteen days after releasing of $H$. convergens combination of adults and larvae, the aphid counts showed more reductions in numbers, being; 190.33, 98.67 and 9.67 aphid individuals/plot, thus indicating reduction percentages of $82.46,91.4$ and $99.14 \%$ for releasing at 1:2, 3:6 and 5:10 (Adults: Larvae/plot), respectively, thus indicating that the highest reduction rate in the infesting aphid counts occurred after13 days by releasing 5 adults: 10 larvae/plot.

A couple of weeks after release, data in Table (5) and Fig. (3) indicated highest efficiency of releasing the mixed stages (adult and larvae) at the highest rate $(5 \mathrm{~A}: 10 \mathrm{~L})$ caused complete disappearance of $A$. craccivora on faba-bean seedlings by the action of feeding of $H$. convergens adults and larvae. At the same time, the lower releasing rates $(3 \mathrm{~A}+6 \mathrm{~L}$ and one adult: 2 larvae) caused 98.14 and $91 \%$ reductions in aphid counts, respectively. Also, two days later (17 days after release), releasing at rate $3 \mathrm{~A}$ : $6 \mathrm{~L}$ was enough to cause disappearance of all the infestations by aphids on faba bean plants, whereas the lowest releasing rate (one adult: 2 larvae) caused $99.43 \%$ reduction in aphid counts than control.

As shown in Table, (5) and Fig. (3), statistical analysis revealed that there were significant differences between mean counts of $A$. craccivora in the control and that in either of the three treatments after releasing a combination of the two stages (adults and larvae) of $H$. convergens. Also, there were significant differences between $A$. craccivora populations before and after releasing at either of the three ratios of adults and larvae. 
Table 4. Effect of releasing $H$. convergens at three different rates of the $3^{\text {rd }}$ larval instar in relation to $A$. craccivora population counts compared to control under semi-field conditions.

\begin{tabular}{|c|c|c|c|c|c|}
\hline \multirow{2}{*}{ No. of Larvae /plot } & \multirow{2}{*}{$\begin{array}{l}\text { Aphid counts } \\
\text { before release }\end{array}$} & \multicolumn{4}{|c|}{ Periods after release } \\
\hline & & 3 days & 5 days & 7 days & 10 days \\
\hline Control & $1104.00 \pm 21.55^{\mathrm{aE}}$ & $1292.67 \pm 46.80^{\mathrm{aD}}$ & $1571.67 \pm 17.32^{\mathrm{aC}}$ & $1764.00 \pm 32.15^{\mathrm{aB}}$ & $1989.67 \pm 30.03^{\text {aA }}$ \\
\hline $3 \mathrm{~L} /$ plot & $1006.67 \pm 44.19^{\mathrm{aA}}$ & $743.33 \pm 38.44^{\mathrm{bB}}$ & $513.33 \pm 14.53^{\mathrm{bC}}$ & $405.00 \pm 25.00^{\mathrm{bC}}$ & $230.33 \pm 7.54^{\mathrm{bD} *}$ \\
\hline Aphid population \% & 100.00 & 73.84 & 50.99 & 40.25 & 22.88 \\
\hline Aphid reduction \% & 0.00 & 26.15 & 49.00 & $\mathbf{5 9 . 7 4}$ & 77.11 \\
\hline 9 L / plot & $1014.33 \pm 52.30^{\mathrm{aA}}$ & $656.67 \pm 27.28^{\mathrm{cB}}$ & $342.00 \pm 29.05^{\mathrm{cC}}$ & $155.33 \pm 10.93^{\mathrm{cD}}$ & $86.33 \pm 6.01 b^{\mathrm{cE} *}$ \\
\hline Aphid population \% & 100.00 & 64.76 & 33.72 & 15.31 & 8.50 \\
\hline Aphid reduction \% & 0.00 & 35.23 & 66.27 & 84.69 & 91.50 \\
\hline 15 Larvae / plot & $998.33 \pm 24.34^{\mathrm{aA}}$ & $600.33 \pm 29.63^{\mathrm{dB}}$ & $236.67 \pm 14.53^{\mathrm{cC}}$ & $93.33 \pm 3.33^{\mathrm{dD}}$ & $30.67 \pm 21.86^{\mathrm{dE}^{*}}$ \\
\hline Aphid population \% & 100.00 & 60.13 & 23.70 & 9.34 & 3.07 \\
\hline Aphid reduction \% & 0.00 & 39.87 & 76.30 & 90.66 & 96.93 \\
\hline
\end{tabular}

$\mathrm{a}, \mathrm{b} \& \mathrm{c}$ : There is no significant difference $(\mathrm{P}>0.05)$ between any two means, within the same column having the same superscript letter.

A, B \& C: There is no significant difference $(\mathrm{P}>0.05)$ between any two means for the same attribute, within the same row having the same superscript letter.

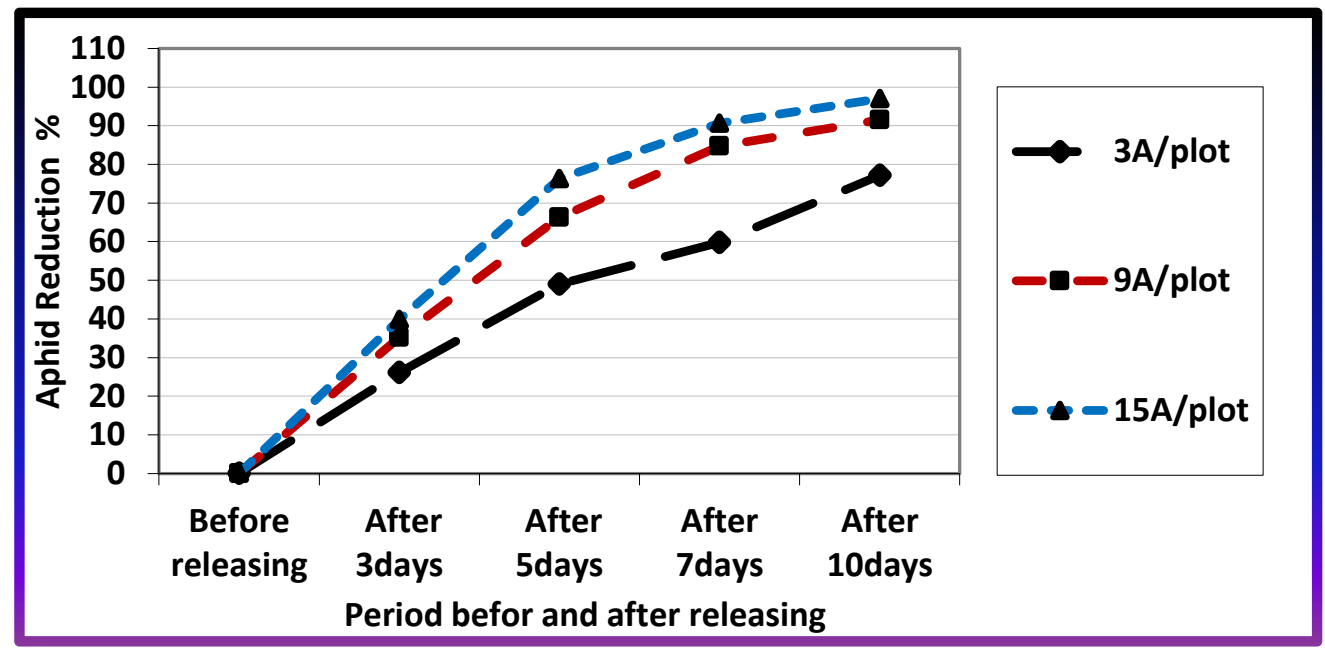

Fig. (2): Reduction percentages in A. craccivora populations after releasing three rates of Hippodamia convergens 3rd instar larvae.

Flint, et al., (1995) stated that release at aggregation-collected Hippodamia convergens significantly reduced populations of melon aphids on potted chrysanthemums and of rose aphids on potted roses. Riddick, (2017) reported that ladybirds are effective aphid predators in greenhouses. Aphid population reduction exceeded $50 \%$ in most studies and ladybird release rates usually did not correlate with aphid reduction. The ratio of aphid reduction/release rate was slightly lower for larvae than adults in some studies, suggesting that larvae were less effective than adults in suppressing aphids. Some adult releases were inside cages, thereby limiting adult dispersion from plants. As a conclusion, the ratio of aphid reduction/release rate was greatest for ladybird adults.

Abd-El-Gawad and El-Zoghbey (2009) showed that after releasing. $C$. undecimpunctata at three rates; 2000 larvae, 6000 adults and combination of 6000 larvae and 3000 adults/feddan/release on cucumber field in Qalubiya Governorate for controlling Aphis gossypii and Myzus persicae, these releases indicated the potential use of this predator to control the targeted aphids on cucumber. Reduction in aphids' populations and subsequent yields were significant. Highest reduction and yield gain was observed when combination of larvae and adults were released. 
Table 5. Effect of releasing $H$. convergens at different ratios of combination of adults and the $3^{\text {rd }}$ instar larvae on aphid population counts comparing with control under semi-field conditions.

\begin{tabular}{|c|c|c|c|c|c|c|c|c|}
\hline \multirow{2}{*}{$\begin{array}{l}\text { ratios of } \\
\text { :larvae /plot }\end{array}$} & \multirow{2}{*}{$\begin{array}{c}\text { aphid counts } \\
\text { before releasing }\end{array}$} & \multicolumn{7}{|c|}{ periods after releasing (days) } \\
\hline & & 3 days & 5 days & 7 days & 10 days & 13 days & 15 days & 17 days \\
\hline Control & $\begin{array}{c}1104.00 \pm 21.55 b \\
\mathrm{cG}\end{array}$ & $\begin{array}{c}1292.67 \pm 46.8 \mathrm{a} \\
\text { F }\end{array}$ & $\begin{array}{c}1571.67 \pm 17.32 \\
\mathrm{aE}\end{array}$ & $\begin{array}{c}1764.00 \pm 32.15 \\
\text { aD }\end{array}$ & $\begin{array}{c}1989.67 \pm 30.03 a \\
C\end{array}$ & $\begin{array}{c}2182.00 \pm 37.85 \\
\text { aB }\end{array}$ & $2353.67 \pm 68.22 \mathrm{aA}$ & $2360 \pm 20.00 \mathrm{aE}$ \\
\hline 1A : 2L/plot & $\begin{array}{c}1085.00 \pm 30.14 \mathrm{c} \\
\mathrm{A}\end{array}$ & $861.00 \pm 4.93 b B$ & $641.67 \pm 7.26 b C$ & $\begin{array}{c}440.00 \pm 15.28 b \\
D\end{array}$ & $323.33 \pm 18.56 \mathrm{bE}$ & $\begin{array}{c}190.33 \pm 2.60 \mathrm{~b} \\
\mathrm{~F}\end{array}$ & $97.67 \pm 1.20 \mathrm{bG}$ & $5.67 \pm 2.96 \mathrm{aH}$ \\
\hline Aphid population \% & 100.00 & 79.29 & 59.14 & 40.55 & 29.80 & 17.54 & 9.00 & 0,52 \\
\hline Aphid reduction \% & 0.00 & 20.71 & 40.86 & 59.45 & 70.20 & 82.46 & 91.00 & 99.48 \\
\hline 3A: 6L/plot & $\begin{array}{c}1147.00 \pm 39.74 a \\
\text { A }\end{array}$ & $\begin{array}{c}748.67 \pm 35.71 \mathrm{c} \\
\text { B }\end{array}$ & $\begin{array}{c}553.33 \pm 26.03 c \\
C\end{array}$ & $\begin{array}{c}369.00 \pm 19.86 c \\
\text { D }\end{array}$ & $224.67 \pm 19.43 \mathrm{cE}$ & $98.67 \pm 3.53 \mathrm{cF}$ & $21.33 \pm 5.81 \mathrm{cFG}$ & 0.0 \\
\hline Aphid population \% & 100.00 & 65.27 & 48.24 & 32.17 & 19.58 & 8.60 & 1.86 & 0.0 \\
\hline Aphid reduction \% & 0.00 & 34.73 & 51.76 & 67.83 & 80.42 & 91.40 & 98.14 & 100.0 \\
\hline 5A: 10L/plot & $\begin{array}{c}1119.00 \pm 62.43 \mathrm{~b} \\
\mathrm{~A}\end{array}$ & $\begin{array}{c}647.00 \pm 32.59 \mathrm{~d} \\
\text { B }\end{array}$ & $\begin{array}{c}457.00 \pm 32.08 d \\
C\end{array}$ & $\begin{array}{c}258.33 \pm 20.12 d \\
\text { D }\end{array}$ & $134.33 \pm 11.35 \mathrm{dE}$ & $\begin{array}{c}9.67 .00 \pm 5.78 d \\
\text { F }\end{array}$ & 0.0 & 0.0 \\
\hline Aphid population \% & 100.00 & 57.82 & 40.84 & 23.09 & 12.00 & 0.86 & 0.0 & 0.0 \\
\hline Aphid reduction \% & 0.00 & 42.18 & 59.16 & 76.91 & 88.00 & 99.14 & 100.0 & 100.0 \\
\hline
\end{tabular}

$\mathrm{a}, \mathrm{b} \& \mathrm{c}$ : There is no significant difference $(\mathrm{P}>0.05)$ between any two means, within the same column have the same superscript letter.

A, B \& C: There is no significant difference $(\mathrm{P}>0.05)$ between any two means, within the same row having the same superscript letter.

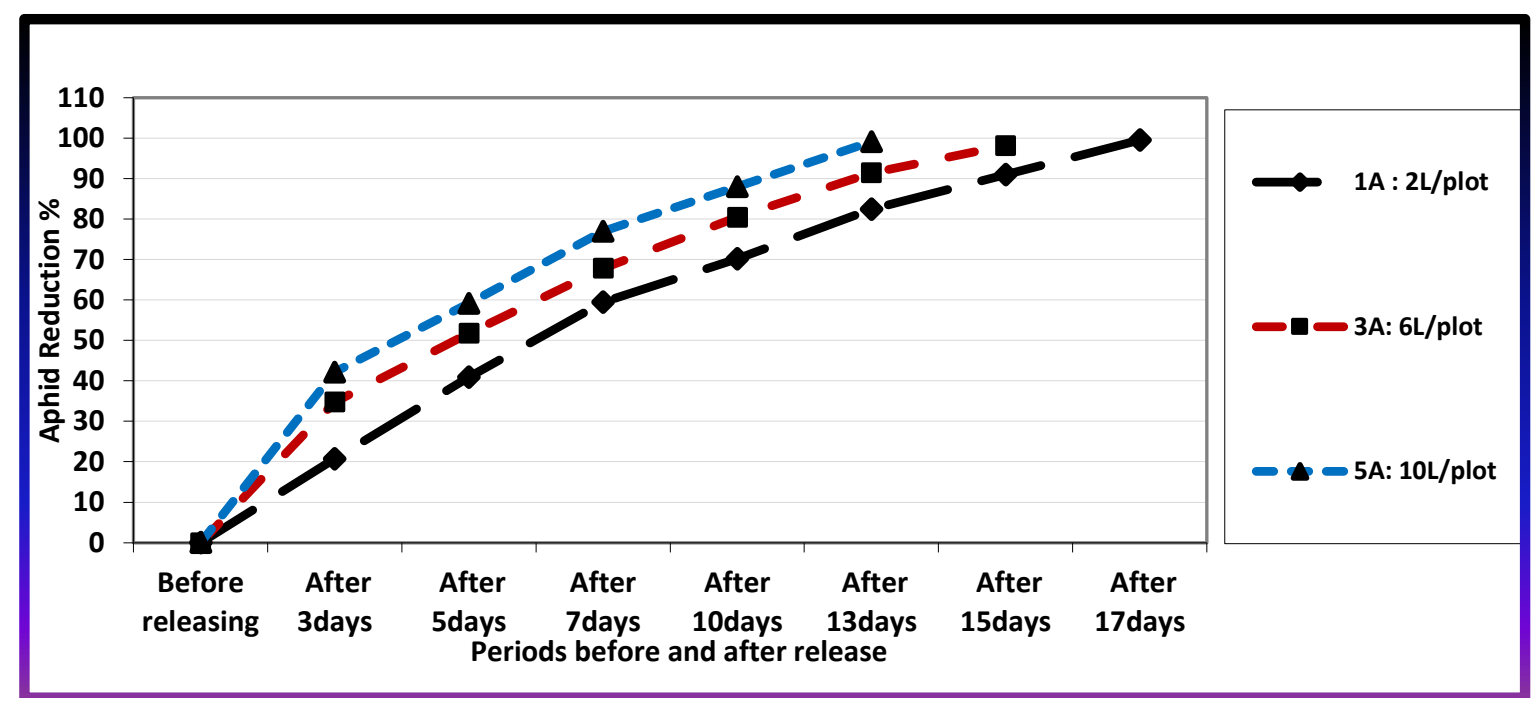

Fig.(3): Reduction percentages in $A$. craccivora populations counts after releasing $\boldsymbol{H}$. convergens adults and larvae altogether at three ratios.

\section{References}

Abd- El-Gawad, A. S. H. and A. A. A. ElZoghbey, 2009. Use the Coccinella undecimpunctata L. for controlling Aphis gossypii Glover and Myzus persicae (Sulzer) on cucumber in Egypt. Egypt. Acad. J. Biolog. Sci., 2(1): 81-85.

Abdel-Salam, A. H. and N. F. Abdel-Baky, 2001. Life-table and biological studies of Harmonia axyridis Pallas (Coleoptera: Coccinellidae) reared on the grain moth eggs of Sitotroga cerealella Olivier (Lepidoptera: Gelechiidae). Journal of Applied Entomol.,125(8):455-462.

Aristizábal, L. F. and P. Steven, 2015. Convergent lady beetle Hippodamia convergens Guérin Méneville (Coleoptera: Coccinellidae). UF/IFAS Extension; The institute of Food and Agricultural Sciences. 
Atlihan, R. and M. B. Kaydan, 2010.Functional response of the coccinellid predator, Adalia fasciatopunctata revelierei to walnut aphid (Callaphis juglandis).Phytopara, 38:23-29.

Bahy El-Din, I. A. and M. A. M. El-Khawas, 2020. Ecological studies on the biological integration occurred by the two predators; Coccinella undecimpunctata L. and Hippodamia convergens Guer. (Coleoptera: Coccinellidae), following the primary parasitism process of the aphids on the wheat plants in Qalubiya Governorate. Egypt. Acad. J. Biolog. Sci., 13(2):229-255.

Buchnan, G. A. 1996. Beneficial insects in the home yard and garden. Georgia Ext. Pub. Bull., 1140: 1-5.

El-Heneidy, A. H.; A. A., Hafez; F. F. Shalaby; and I. A. Bahy El- Din, 2008. Comparative biological aspects of the two coccinellid species; Coccinella undecimpunctata L. and Hippodamia convergens Guer. Under laboratory conditions. Egyptian Journal of Biological Pest Control, 18(1):51-59.

Flint, M. L.; S. H. Dreistadt; J. Rentner and M. P. Parrella, 1995. Ladybeetle release controls aphids on potted plants. California Agriculture, 49 (2):1-8.

Hale, M. A. and D. Elliott, 2003. Successes and challenges in augmentative biological control in outdoor agricultural applications: a producer's perspective. First International Symposium on Biological Control of Arthropods, Honolulu, HI, pp:185-188.

Lee, J. H., and T. J. Kang, 2004. Functional response of Harmonia axyridis (Pallas) (Coleoptera: Coccinellidae) to Aphis gossypii Glover (Homoptera: Aphididae) in the laboratory. Biol. Cont., 31: 306-310.

Lohar, M. K.; S. N. Khuhro; M. H. Lakho; G. A. Magsi and T. A. Khuhro, 2012. Biology and feeding potential of predator, Hippodamia convergens Guir, (Coleoptera: Coccinellidae) on mustard aphid Lipaphis erysimi (Kalt.) in laboratory. Pak. J. Agri., Agril. Engg., Vet. Sci., 28 (2): 150-159.

Lyon, W. F. 1998. Horticulture and crop science fact sheet: Lady Beetle". Ohio State University Extension, Fact Sheet.

Lyon, W .F. 2001. www.ag.ohiostate.edu/ohioline/hyg act/2000/2002.html.

Omkar, P. A. 2004. Prey-dependent life attributes of an aphidophagous ladybird beetle, Propylea dissecta (Coleoptera: Coccinellidae). Biocontrol Science and Technology, 14 (4): 385-396.

Ramírez, C. S. D.; M. D. Araiza; O. Alejandro, 2019.Predation capability of Hippodamia convergens (Coleoptera: Coccinellidae) and Chrysoperla carnea (Neuroptera: Chrysopidae) feeding of Melanaphis sacchari (Hemiptera: Aphididae). Florida Entomologist., 102 ( 1) : 2528.

Riddick E. W., 2017. Identification of conditions for successful aphid control by ladybirds in greenhouses, Insects, 8 (38)1:17.

Schirmer, S.; P. Blaeser and C. Sengonca, 2006. Comparative studies on the suitability of two aphelinids, Aphelinus asychis Walker and Aphelinus varipes (Hym: Aphelinidae), for the biological control of Aphis gossypii Glover. Mitteilungen der Duutschen Gesellschaft fur allgemeine und angewandte Entomologie, 15:289:293.

Shrestha, R. B., and M. N. Parajulee, 2013. Potential cotton aphid, Aphis gossypii, population suppression by arthropod predators in upland cotton. Insect Sci., 20 (6): 778-788.

Steel, R., J. Torrie, and D. Dickey, 1997. Principles and procedures of Statistics: A Biometrical Approach, $3^{\text {rd }}$ ed., McGraw-Hill, New York, NY.

Yu, J. Z.; H. Chi and B. H. Chen, 2013. Comparison of the life tables and predation rates of Harmonia dimidiate (F.) (Coleoptera: Coccinellidae) fed on Aphis gossypii Glover (Hemiptera: Aphididae) at different temperatures. Biol. Cont., 64 (1):1-9. 


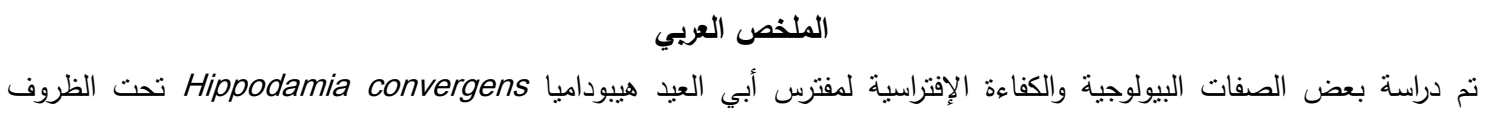

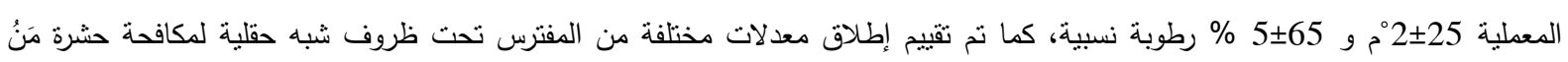

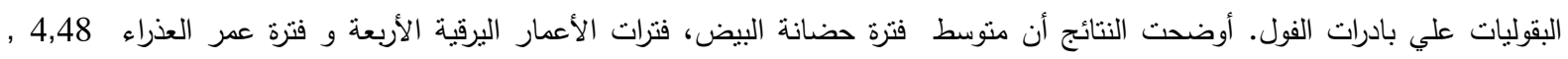

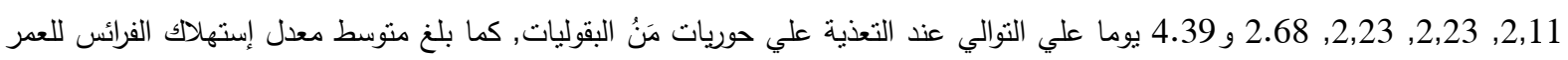
البرقي الرابع للمفترس 84,47 حورية مَنُ بقوليات (عمر رابع) وكان العمر اليرقي الرابع الأكثر شراهه في إستهلاك حوريات المَنُ مقارنه بالأعمار

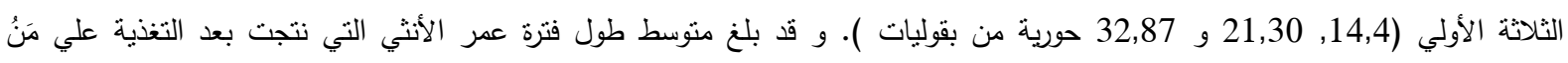

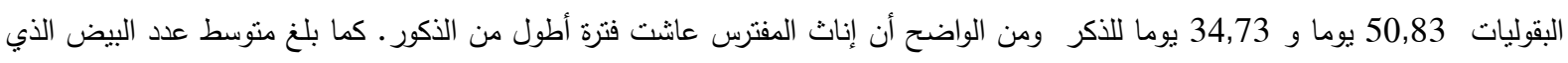
وضعته الأنثي 455,13 بيضة. كما أنه تحت ظروف الصوبة نم تقييم كفاءة المفترس بعد إطلاقه لمكافحة حشرات مَنُ البقوليات علي بادرات الفول كالآتي؛ إطلاق للحشرث الكاملة فقط, إطلاق العمر اليرقي الثالث فقط و إطلاق كلا من الطورين معا. كلا من الثلاث معاملات أدت إلي بلثي نسب خفض في تعدادات المن مقارنة بالكنترول وكان معدل الإطلاق في الثناث معاملات 3, 9 و 15 مفترس / قطعة تجريبية. وكانت أعلي

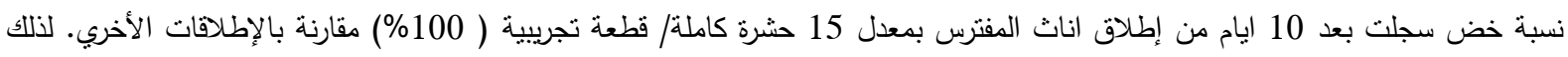
تعتبر الحشرات الكاملة للمفترس هي الأفضل من خلال نتائج هذه الدراسة لمكافحة الإصابة بحشرة من البقوليات. 